\author{
Amilkar Kosiński \\ Uniwersytet Łódzki \\ Wydziat Filozoficzno-Historyczny \\ amilkar.kosinski@uni.lodz.pl
}

\title{
Przesiedleńcy ze wschodnich obszarów II Rzeczypospolitej po II wojnie światowej w relacji podróżnika rowerowego ${ }^{1}$
}

„Migrację Polaków z Kresów po drugiej wojnie światowej, potocznie określaną mianem repatriacji, należałoby nazwać raczej przesiedleniem (często przymusowym), a czasem wręcz wypędzeniem. [...] trudno jest tu mówić o repatriacji, która jest rodzajem reemigracji, powrotu do ojczystego kraju osób, które wskutek różnych wydarzeń znalazły się poza jego granicami"2.

Przytoczone poniżej trzy fragmenty „Dzienników rowerowych” ukazują losy przesiedlanych Polaków, będące ścisłym odniesieniem do wydarzeń politycznych, wydawać by się mogło już zamierzchłych, bo dotyczących okresu powojennego. Z perspektywy mieszkańca Polski centralnej wydarzenia związane z powojennymi przesiedleniami na tzw. Ziemie Odzyskane wydają się być marginalne i tracące na aktualności. Wyrosły bowiem kolejne pokolenia, zasymilowane z nowymi ,małymi ojczyznami”, a „,[...] Integracja tego migracyjnego tygla trwa do dzisiaj, przynosząc niezwykle ciekawe wyniki społeczne, kulturowe, ale także polityczne i gospodarcze. Żywe są w tej części Polski tradycje kresowe, a jednocześnie stąd pochodzą posłowie niemieccy do Sejmu, a Szczecin jest znaczącym ośrodkiem kultury ukraińskiej"”.

Wystarczy jednak dotrzeć na prowincję, do miejsc zamieszkiwanych przez uczestników tamtych wydarzeń, wsłuchać się w ich narrację, by przekonać się jak wciąż żywe są ich traumatyczne wspomnienia, a życie zdominowane nowymi okolicznościami, w których musieli się odnaleźć i oni sami, i ich rodziny.

Prezentowane opisy dotyczą zarówno przesiedleń z Kresów Wschodnich, jak i późniejszych migracji wewnątrz kraju. Ukazują także niezwykle skomplikowane tło i dzisiejsze realia obszarów objętych tymi zdarzeniami. Przesiedlenia

1 Całość relacji zamieszczono w książce A.G. Kosiński, Dzienniki rowerowe 2008-2011, Łódź 2018, szczególnie rozdz. I, s. 19, 26 i nast., rozdz. II, s. 82, 128 i nast., rozdz. III, s. 222 i nast., rozdz. IV, s. 464 i nast.

2 J. Kochanowski, Deportacja zwana repatriacja, ,Polityka. Pomocnik Historyczny - Z Kresów na Kresy", 12.09.2016, s. 1.

3 Tamże, s. 8. 
kresowe są problematyką często poruszaną w literaturze historycznej ${ }^{4}$, a wywodzącą się z wydarzeń determinowanych II wojną, w tym polityką Stalina wobec ludności zamieszkującej rejony dzisiejszych państw: Litwy, Białorusi i Ukrainy oraz Rosji ${ }^{5}$. Przesiedlenia wewnętrzne na terenach Polski Ludowej, w nowych granicach wytyczonych po 1945 roku, będące również konsekwencją ich późniejszych korekt, tu w przytoczonych fragmentach dotyczą ruchów ludności w obrębie tzw. Polski lubelskiej.

Trasy wypraw rowerowych w większości planowane były wzdłuż granic państwa. Przemieszczając się w ten sposób, można było dokładnie śledzić historię odwiedzanych miejsc, poznając ją niejako „w realu” oraz nawiązywać bezpośredni kontakt z mieszkającymi tam obecnie dawnymi mieszkańcami wschodnich rejonów Rzeczypospolitej.

\section{Ołownik nad Węgorapą, 10.07.2009 r. (woj. warmińsko-mazurskie)}

„[...] Tuż za Mieduniszkami wyłonił się przed nami mały mostek, byłem przekonany, że to już Kanał Mazurski. To efekt zbyt pobieżnego studiowania przeze mnie mapy. Stanęliśmy na moście. Pod nami płynęła mityczna Angrapa,

$4 \quad$ Np.: P. Bojarski, Bagaż doświadczeń $i$ wspomnień: relacje osadników polskich na Warmii i Mazurach po 1945 roku, Olsztyn 2017, ss. 191; J. Czerniakiewicz, Przemieszczenia Polaków i Żydów na Kresach Wschodnich II Rzeczypospolitej i w ZSRR: 1939-1959, „Studia i Materiały”, z. 21, Warszawa 1991, ss. 15; tegoż: Przemieszczenia ludności polskiej z ZSRR 1944-1959, Warszawa 2004, ss. 80; J. Czerniakiewicz, M. Czerniakiewicz, Przesiedlenia ze Wschodu 1944-1959, Warszawa 2007, ss. 157; P. Eberhardt: Migracje polityczne na ziemiach polskich (1939-1950), Wrocław 2010, ss. 264; B. Halicka, Polski Dziki Zachód: przymusowe migracje i kulturowe oswajanie Nadodrza 1945-1948, Kraków 2015, ss. 434; K. Kersten, Repatriacja ludności polskiej po II wojnie światowej: studium historyczne, Wrocław 1974, ss. 274; M. Latuch, Repatriacja ludności polskiej w latach 1955-1960 na tle zewnętrznych ruchów wędrówkowych, Warszawa 1994, ss. 260; L. Olejnik, Polityka narodowościowa Polski w latach 1944-1960, Wyd. UŁ 2003, ss. 640; M. Ruchniewicz, Repatriacja ludności polskiej z ZSRR w latach 1955-59, Warszawa 2000, ss. 402; S. Rymaszewski, Wykarczowani zza Buga, Gdańsk 2001, ss. 592; J. Siedlecki, Losy Polaków w ZSRR w latach 1939-1986, Warszawa 1989, ss. 404; i in.

5 „[...] trudno jednoznacznie stwierdzić , jakie były ostateczne plany Stalina wobec [...] mieszkańców (Kresów - przyp. A.K.), zwłaszcza Polaków. Czy ograniczyłby się do usunięcia niebezpiecznych elit (co w dużej mierze zrobił), czy też - gdyby nie doszło do wojny niemiecko-sowieckiej i reżim komunistyczny ustabilizowałby się na Kresach - kolejnym krokiem byłaby ich homogenizacja narodowościowa, połączona z masowymi przesiedleniami Polaków i zapewne Żydów? [...] Kierunek realny nadała jej agresja niemiecka na ZSRR 22 czerwca 1941 r., która radykalnie zmieniła sytuację dawnych wschodnich rejonów Polski. W ciągu dwóch lat społeczność żydowska Kresów została praktycznie unicestwiona. Wkroczenie Niemców doprowadziło także do uaktywnienia się nacjonalistów ukraińskich, liczących na stworzenie własnego państwa. Wpłynęło to na podjęcie przez kierownictwo OUN decyzji o usunięciu polskiej ludności ze wszystkich spornych terytoriów i w rezultacie do krwawych czystek etnicznych na Wołyniu w Galicji Wschodniej [...]"; J. Kochanowski, dz. cyt., s. 1. 
Węgorapa czy też jeszcze Gołdapa. Na tym odcinku akurat prosta, ale jak wynikało z mapy, meandrująca silnie niżej, na północy. Toczyła wody bystro, biorąc początek z jeziora Mamry, by zasilić Pregołę i z nią zniknąć w Zalewie Wiślanym.

Tego dnia długo jeszcze trudziliśmy się, jadąc przez ogromne i puste przestrzenie. Pod wieczór wyjechaliśmy na drogę do Węgorzewa. Na pustej szosie dogoniła nas, zmęczonych, „miejscowa” na rowerze. Widziałem w lusterku z jakim zaciekawieniem odpytywała Ewę. Bez przekonania zagadnąłem o miejsce na nocleg. Padła propozycja - może w szkole? Podjechała tam z nami. Przed budynkiem szkolnym pustym i wakacyjnie leniwym, pod parasolem, przy grillu, siedziała tamtejsza elita. Dyrektor i nauczyciele z rodzinami. Pili piwo i przegryzali skwierczącą kiełbaską. Nie znaleźli dla nas miejsca. Nie byli tym zainteresowani w żadnym stopniu. Nasza towarzyszka zaś wykazywała niesamowitą inwencję, by ulokować nas gdzieś pod dachem. Wówczas wyraźnie oświadczyliśmy zgodnym chórem, że szukamy jedynie miejsca pod namiot. W odpowiedzi padła propozycja nie do odrzucenia. Ta pozornie wścibska kobieta zagarnęła nas do siebie. Tam przesiedzieliśmy, jak u Pana Boga za piecem, dwie doby, rozkoszując się spokojem miejsca i niezmierną serdecznością gospodarzy. Rozłożyliśmy namiot na łące pośród pokosów suszonej trawy. Całość była na nieznacznym wzniesieniu, na tyle jednak górującym nad okolicą, że widzieliśmy wszystko po horyzont. $\mathrm{Na}$ jego linii zieloność tej i kolejnych łąk i pojedyncze kępy drzew schodziły się $\mathrm{z}$ niebem w pierzastych obłokach. Byliśmy kilometr od granicy, trochę ponad dziesięć od Rapy i tyleż przed Węgorzewem. Osada nazywała się Ołownik, a nasi uczynni gospodarze - Irena i Mikołaj F. Poznaliśmy także siostrę gospodarza Teresę, przybyłą z nieodległego Olsztyna, a przebywającą tam z wakacyjną wizytą.

By trafić na tę łąkę należało zjechać z głównej drogi dobrych kilkadziesiąt metrów. Tam dopiero ukazywało się mikroskopijne gospodarstwo Ireny i Mikołaja. Zabudowania gospodarcze i mały poniemiecki dom $\mathrm{z}$ dwuspadowym dachem z czerwonej dachówki, pięterkiem i z malutkimi pokoikami. Ci, którzy go budowali, nie byli zbyt zamożni, ale dom usytuowano urokliwie. Nasi gospodarze otoczyli go zielonym podwórkiem i ogrodem, z płotem z drewnianych sztachet. Przebijały przez nie bujna trzmielina i paprocie. Obok, na wschodnią „modłę”, urządzono z wikliny kojce dla drobiu [...].

Rozłożyłem namiot i zauroczony przechadzałem się po łące. Przepiękne miejsce i taki w nim spokój, a dla nas jeszcze coś niezwykłego - fala serdeczności jaką zalali nas gospodarze. Dobrze nie okopaliśmy się na stanowisku, już pani Irena tonem nieznoszącym sprzeciwu prosiła na kolację. Tam zaś gościnny stół i dla strudzonych wędrowców łazienka do dyspozycji. Doszliśmy do wniosku, że to ten $\mathrm{z}$ momentów trafiających się w podróży, kiedy warto zatrzymać się na chwilę, odpocząć, poczuć aurę miejsca. Wieczór upłynął nam na serdecznej gawędzie. Później kleiły się oczy ze zmęczenia i od ogromnej ilości wrażeń. Od tych przestrzeni, tego kłębiastego nieba nad głowami. Wieczorną porą, pachnącą skoszonym sianem, wsunęliśmy się w śpiwory, nasłuchując dłuższą chwilę jak łąka wibruje chórem cykad. 
Niezbyt późnym rankiem, ale z wysokim już słońcem, ante portas naszego obozu zameldowała się pani Irena, prosząc na śniadanie. Tonu nie zmieniała. Leżąc w namiocie, oczyma wyobraźni widziałem celującą w nas kałasznikowem, tak na wszelki wypadek, gdybyśmy chcieli odmówić ich gościnie. Kawę wypiliśmy wspólnie, pogadując. Później leniwie spędzaliśmy czas, łażąc po obejściu. Zajrzeliśmy do ogródka, gdzie ku mojej wielkiej radości rosła grządka zielonego słodkiego groszku. Sytuacja szła jednak w tym kierunku, że bylibyśmy wciąż zapraszani [...]. Postanowiliśmy przejąć inicjatywę. Wybraliśmy się na zakupy do Węgorzewa, serwując po powrocie obiad.

Jeździliśmy po miasteczku, zwiedzając. Przedwojenny Angerburg, przez Polaków nazywany Węgoborkiem, to miasteczko o siedemsetletniej historii. Po wytępieniu plemion pruskich osiedli tu Krzyżacy, budując zamek u wyjścia Węgorapy z Mamr. Tak się zaczęły jego dokumentowane dzieje. Przed II wojną był tu kurort, port jachtowy, stacja kolejowa, restauracje, hotele, jak to „za Niemca”. W styczniu 1945 roku bracia Słowianie z krasnoj zrobili porządek z tymi nazistowskimi miazmatami. Czynili to z zapałem i na tyle skutecznie, że w proch obrócili $80 \%$ zabudowy miasta. Żeby Polacy mieli czym się później zająć. Zbyt wielu zabytków więc nie dane nam było podziwiać. Nowocześnie wyglądająca marina robiła za to miłe wrażenie. Tym ciekawsze to dla nas, żeśmy obydwoje z tych pełzających, aniżeli pływających. Udało nam się kupić świeżą płoć i sielawę, kiszkę ziemniaczaną, ten litewski rarytas; coś tam do popicia tego, na rowery i powrót. Musieliśmy przecież przygotować posiłek.

Na łące obok namiotu ustawiliśmy stól, ławki i grill. Panie Irena z Teresą serwowały sałatki. Ja w kucki, na gazowym patronie usmażyłem natarte czosnkiem płocie i sielawy. Ewa zaś podawała kiszkę ziemniaczaną z grilla. Taką była uczta nasza.

Myli się ten, kto przypuszczałby, że nasz pobyt w Ołowniku, na oddalonej od świata rajskiej łące, pozostawał niezauważalny dla postronnych. Oto przy stole rozsiadła się Regina, sąsiadka naszych gospodarzy, zamieszkująca w centrum wsi $\mathrm{w}$ popegeerowskim bloku. Widzieli nas i inni, podążających karawaną z tą śmieszną przyczepką, obładowanych po uszy. Owa Regina przybyła więc, by przyjrzeć nam się z bliska. Czułem się jak biały nosorożec na safari:

- Takie cudze ludzie, a takie fajne. Ty Irena to masz szczęście. Idziesz droga $i$ spotykasz takie cudze ludzie. A ja samotna, ja chodze wieczorem sama po drodze i nikt taki nie nadjedzie. Ale gdzie też ja by mogła takich u siebie gościć, w tym małym pokoiku. A przysztyby do mnie w gościnę?

- A czemu nie? - odpowiedziałem, bo Regina z blokhausu całkiem sympatyczna. I tak, w tę wieczorną porę, zszedł nam temat na koleje ludzkiego losu, które sprowadziły obecnych w to miejsce. Pan Mikołaj, gdzieś z okolic Krasiczyna. Pani Irena, o ile dobrze zapamiętałem, z Lubartowa. Regina, sąsiadka, dotarła tu jako trzynastolatka $\mathrm{z}$ terenów dzisiejszej Białorusi, na fali kolejnej repatriacji lat 50. XX w. Jakby dla podkreślenia tego zaczęła śpiewać po białorusku i rosyjsku melodyjnie pieśni. Wydały mi się dziwnie znajome. Po chwili rozpoznałem, że to te same, które Czesław Niemen nagrał na analogową płytę z unikatowej serii „Biały kruk czarnego krążka”: (Russische Lieder) (!) Mam tę płytę do 
dziś i rozpoznaję tekst: ...jołoczki, siosionoczki, zielonyje, kaluczije, (jodełki, sosenki, zielone $i$ ktujące) i pieśń o wędrowcy: Gdzie Bajkat do morza dosięga / przez śniegi, wichurę i noc / wędruje zgarbiony włóczęga / dźwigając przeklęty swój los... - śpiewała po rosyjsku i po polsku, melodyjnie, pięknie.

Ochrzciłem panią Reginę przydomkiem - piewica, tak bardzo to do niej pasowało, ale nie wzbudziło jej entuzjazmu. W mroku wieczoru, który spływał na tę pachnącą sianem łąkę, staliśmy się też świadkami wzruszającej opowieści o jej losach:

- Ruskie! Ile ja za to wycierpiałam. Suki ruskie. Tyle co ja od męża wycierpiałam za te Ruskie, to ja mu chyba w życiu nie wybaczę. Nie wiem dlaczego tak mówił. Bo jego matka była Niemka. Zimmermann to chyba niemieckie nazwisko?

My z mama przyjechaliśmy tu we dwie w 1957 roku. Ja chodziłam na Litwe do szkoty 6 klas, na Białoruś chodziłam rok, a później siódma klasę tu w Sobiechach kończyłam ja. A jak ustyszę kogoś, że ktoś po rusku rozmawia, nie wiem, to dla mnie serce raduje się. Nie wiem dlaczego, przecież ja tu nigdzie nie mam ani rozmowy, ani styczności $i$ nic w ogóle... Albo kiedyś moja ciotka, mojego ojca siostra, siedziała tam, gdzie dziadek, w Mińsku w więzieniu, pięć chyba lat. I takiej piosenki się nauczyła: ,,jesiennyj dbalnyj wiecieroczek/ za czem ty dujesz tak chaładno/gulaju dietka na swabodzie/ a mnie ze resztkoj wsio adno...". Jak wróciła $z$ więzienia mówi do mnie, ty Renia, naucz się tej piosenki, a może kiedyś komuś zaśpiewasz? To jest więzienna piosenka.

Kiedyś tak było po wojnie, jeszcze byłam mała, mieszkałam niedaleko Soleczników, na wsi na gospodarce z dziadkami, to znaczy z mamy teściami. Kiedyś moja mama, ta ciotka, siostra ojca, mamy siostra, mamy brat, no tak, jak to mtodzież w zimę, poszli tam do Stanisławskich, na wiés. W wieczór grali w karty, no $i$ tak się zebrali. Byt taki partyzant, co się ukrywat $i$ on byt polskim partyzantem. I go Ruskie ścigali. No i on przyszedt do nich i powiedziat: ja robię zabawe, macie tańczyć. I wszyscy tańczyli. I ja tam byłam z mama. Ale ten partyzant przywiózt takiego, z innej wioski, niewidomego grajka. On grat na akordeonie $i$ wszyscy musieli tańczyć, bo partyzant miał taka, jak to dziś pamiętam, taka miat broń. I nie wiem, jak to sie nazywa, tu była taka lufa, a tu taka taśma szła. Okragła duża taśma do strzelania. No i wszyscy musieli tak tańczyć, jak ten partyzant kazat. No i ten grat, wszyscy tańczyli.

A dziadek był gospodarzem. Na gospodarce Stanisławski był mój dziadek. Później kazali tego grajka niewidomego odwieźć do domu, a ten partyzant poszedt sam do siebie. To byto z soboty na niedziele. Tam byty takie Sowietsity i ten grajek pojechat, $i$ to wszystko zameldowat. I kogo po głosie poznat? Mamy brata, mamy siostre, dziadka. Zameldowat, że była balanga $i$ ze wszyscy tańczyli. A mojej mamy i mnie nie poznat ten niewidomy grajek po głosie. I tym ja, i moja mama uszliśmy bez kary.

A ten mój dziadek Stanisławski, co to była jego gospodarka, miał mieszkanie, miat magazyn, miat obore, konie miat, to on dostat tak! Dlaczego on nie zameldowat rano, że tam byt partyzant, bo jego Ruskie poszukiwali.

To ja ttumaczę, to co ja zapamiętałam. Który to rok? W 1957 przyjechałam, a tam chodziłam jeszcze do szkoty, to może byt 1948-1949? 
My z mama w niedziele poszliśmy do Waliszek do kościoła, przychodzimy z powrotem:

- Ty, Renia, idziemy do dziadka. Bo ja mieszkałam z mama u ojców Mićkiewiczów, a to było u Stanisławskiego.

- Ty, mówi. Co tam się robi u dziadka, Matko Boska! My poszliśmy z mama tam, była juz milicja, byto wszystko, wszyscy byli aresztowani. Mojej mamie się upiekto.

Jak wybuchta amnestia, Stalin jak zmart, to wszyscy powracali do domu, do mojej mamy do Wilna, do tych teściów. Więc byto bardzo nas dużo, a wtedy w tym roku to werbowali na „celeniu”, musze przypomnieć, jak to się nazywało - na „,celeniu”! Tam daleko, gdzie Kozacy, na kozacka stronę. Tam wyjechali, a później stamtad pojechali na Kaukaz.

Ja z mama i z tymi dziadkami tak sobie mieszkatam, a ten mój dziadek Stanistawski, mamy ojciec to został $w$ kotchozie $w$ Michaliszkach. Pasł owieczki $i$ z macocha sobie żyt. Tak to byto $w$ mojej rodzinie.

A my z mama przyjechaliśmy tutaj. A dziadek, że nie zameldowat to miat konfiskatę mienia i dostat 10 lat ciężkiego więzienia. Renia! Jedziemy do Polski. Co mamy tu robić. Przyjechaliśmy do Polski i „, pajdu dziewoszki radnoj... ". I tak zostałam dujka w pegeerze.

Późnym wieczorem zapadła decyzja - odprowadzimy do domu piewicę. Panie narzuciły polary, ruszyliśmy przez pachnącą, ciepłą, lipcową noc do nieodległego „city” Ołownika. W centrum wsi zatrzymaliśmy się na chwilę przy rozświetlonej elektrowni wodnej na Węgorapie. Elektrownia sprawna i działająca, w rękach prywatnych, choć był taki moment, że skazano ją na zagładę. Ołownik przed wojną nazywał się Leuningken i był w posiadaniu rodu von Sauden, gospodarzącego tu na 12000 hektarów. Elektrownia była przemyślaną inwestycją zaopatrującą w prąd cały majątek, od lat 20 . XX w. Przetrwała wojnę. Dziwnym zrządzeniem losu nie została wywieziona przez Rosjan. W każdym razie, po małym remoncie dokonanym przez Polaka Feliksa Jancewicza, żołnierza frontu białoruskiego, podjęła produkcję prądu w 1948 roku. Bez specjalnych napraw dotrwała do połowy lat siedemdziesiątych. W zindustrializowanej i zelektryfikowanej dekadzie towarzysza Edwarda, poniemiecki zabytek nie miał prawa trwać dalej. Jego remonty dla nikogo nie były opłacalne. Zabytkowe turbiny z 1918 i 1920 roku pojechały na przyczepie za traktorem z lokalnego POM-u, wprost na złom. Po latach to wszystko co pozostało opłaciło się wyremontować zamieszkującemu w Norwegii panu Jerzemu Marszałkowi i wznowić produkcję prądu. Kiedy ruszyły dwie turbiny produkujące $200 \mathrm{~kW}$ energii, do pogłaskania głów ustawiło się wielu. Ale wielu, wcześniej, skutecznie oprotestowywało inwestycję, zarzucając jej niezgodność z planem zagospodarowania przestrzennego gminy. Tak to już bywa. Najbardziej zgodne z planami zagospodarowań przestrzennych gmin są ruiny i nieużytki.

Wracaliśmy; Ewa z panią Ireną pod rękę, tak przypadły sobie do serca; ja w parze z panią Teresą. Nieśpiesznie. Nad nami rozgwieżdżone niebo i tylko słychać cykady. Od rana zaś czekało nas pakowanie i dalsza droga. I żal było wyjeżdżać. Czułem, ten wieczór to sprawił, że my już swoje, a nie cudze ludzie. 


\section{Radruż, 7.07.2011 r. (woj. podkarpackie)}

[...] W Chotylubiu, na wzniesieniu obok drogi, cierpliwie trwała drewniana trójdzielna cerkiewka wzniesiona w 1888 roku. Druga w tym miejscu od XVI wieku. Wrażenie smutne. Kopuły i dach pokryte przerdzewiałą blachą. Zrębową konstrukcję toczył kornik. Murowana dzwonnica ograbiona z dzwonów. Dyżur pełniła malutka sygnaturka. Wokół panował spokój, jak na leniwy słoneczny lipcowy dzień przystało. Odpoczywaliśmy po zwiedzaniu, przysiadając na progu.

Wszystkie mijane świątynie obecnie będące kościołami katolickimi pozamykane na cztery spusty. Nie udało nam się nawet zajrzeć do środka przez okno. Okolica malownicza i piękna. Od Nowego Sioła towarzyszyła nam zarośnięta struga o pięknej nazwie Brusienka. Jedynie napotykane mogiły i pomniki ustawiane na poboczach drogi przypominały, że ten sielsko wyglądający teren, tak bardzo spływał krwią. Oto przy zbiegu dróg ustawiono ogromną, nieociosaną bryłę bruśnieńskiego „wapniaka”. W nią wmontowano płytę i krzyż. Napis na płycie: Ta ziemia jest uświęcona krwia niewinnie pomordowanych mieszkańców wsi Rudka przez bandy UPA. W tragiczna noc 19 IV 1944 roku stracito życie 62 mieszkańców, a wieś została spalona.

Dojechaliśmy do przepięknie położonego Nowego Brusna. Kilkaset metrów na wschód, w głębi wsi, na wzgórzu, wśród potężnych lip stała cerkiew... Smutku mój, co za przygnębiający widok. Stała drewniana ruina cerkwi. Pusta skrzynia popodpierana ze wszystkich stron drągami. Na jej trzech kopułach płaty blachy, eternitu, papy i... resztka dawnej świetności, fragmenty kryte gontem. Okna zabite deskami, także wejście. A w nich wyszarpana dziura, przez którą wchodzili ciekawscy. Wszedłem i ja. Widok ściskający serce. Wybebeszone, odarte do gołej konstrukcji wnętrze bez podłogi. Słońce wciskało się przez szpary w ścianach i dachu. Podświetlało od dołu, przedzierając się pod belką zrębową, opartą na „peckach” i głazach. Przy wejściu, na wygiętych drągach przerzuconych między ścianami, poukładane jedne na drugich ławki. Pomazane czymś, porzucone. Wnętrze było ciemne, w kolorze ciepłego starego brązu. Nad głową miałem zdartą do gołych dech kopułę, w szczycie której przez latarnię sączyło się słoneczne światło. Kiedy podniosłem do góry obiektyw aparatu, ze szczeliny kopuły, przestraszony moim wejściem, bezszelestnie wyleciał nietoperz. Po sekundzie zniknął. Co za smutny i przygnębiający widok. Przypomniały mi się inne ruiny. Resztki kościoła pod wezwaniem św. Antoniego w podbiałostockiej Jałówce. Budowla, choć dużo młodsza, bo z 1908 roku, zniszczona przez wycofujących się Niemców w 1944 roku. Tam, w okaleczonych murach trwała jakaś monumentalna uroda. W Bruśnie, pozostałości pięknej kiedyś trójkopułowej cerkwi z 1713 roku pod wezwaniem św. Paraskewy, były tragiczne. Były niemym wyrzutem obojętności, ignorancji, o odwrócenia się plecami; historii, której zmienić nie można. To miejsce tak podziałało na nas, że zrobiliśmy dłuższą przerwę w podróży. Rozłożyliśmy się na skraju przycerkiewnego wzgórza. Wyciągnąłem przewodnik. Doczytaliśmy reszty historii. Znajdowaliśmy się w obszarze politycznych zmagań i nacisków sięgajacych końca XVIII wieku. Brusno zamieszkiwane przez prawosławnych, katolików i Żydów, w połowie lat 80 . XVIII stulecia poddane zostało 
planowej akcji osadniczej. Ta tak zwana Josephinische Kolonisation, (prowadzona przez cesarza Józefa II) pod hasłem uprzemysławiania terenów dzisiejszej południowo-wschodniej Polski, sprowadziła tu ponad 3000 rodzin kolonistów austriackich i niemieckich. W sumie w całym rejonie 18000 ludzi. Brusno zostało podzielone na trzy części: Stare, Nowe i Deutschbad, dzisiejszą Polankę Horyniecką. Prócz prawosławnych Rusinów, katolików Polaków, Żydów i Czechów, zamieszkali tu austriaccy kalwini, niemieccy luteranie, rzemieślnicy i wykwalifikowani rolnicy, trudniący się planową hodowlą zwierząt, nowoczesną uprawą roli czy produkcją w rodzinnych zakładach rzemieślniczych. Koloniści przetrwali z górą trzy pokolenia, do 1944 r. Exodus Niemców zaczął się już w 1940 roku, na mocy porozumień między Sowietami a III Rzeszą. Nie byli to bogaci osadnicy, nie dorobili się fortun, żyli jednak w miarę dostatnio. Nie można porównywać ich zamożności z tymi z Europy Zachodniej. Ale tu, na warunki galicyjskie... A potem przyszły wojny światowe. Zwłaszcza druga. Nad to przepiękne miejsce nadciągnęła czarna noc. Ukraińcy i Niemcy mordowali Polaków i Żydów, a potem zaczęli mordować się wzajemnie, choć wszyscy przez całe lata żyli obok siebie i pod jednym niebem. Po latach, we wsi Brusno próżno szukać śladów po dawnych mieszkańcach. Jedynie za prawosławną świątynią świętej Paraskewy ostały się malowniczo wyglądające nagrobki poryte epitafiami, zaczynające się od słów: Tut spoczywaje..., Hier Ruht..., Tu spoczywa ... Nie napotkaliśmy cmentarza żydowskiego w Bruśnie.

Odpoczywaliśmy u podnóża tego co zostało z cerkwi. Zaczęły nadjeżdżać grupy, jak się okazało, uczestników wczorajszego „Folkowiska”6 w Gorajcu. Część na rowerach, część samochodami. Auta na rejestracjach wrocławskich i szczecińskich. Grupa rowerowa z młodym przewodnikiem o wyglądzie nawiedzonego mistyka przechadzała się tuż obok. Słyszeliśmy jego wyczerpujące informacje o budowli. Opowiadał bardzo młodym ludziom o zgromadzonych tu materiałach budowlanych i przybyłych specjalistach od drewnianych konstrukcji. Około 2000 roku podjęli się oni generalnego remontu cerkwi. Rozpoczęto prace, a wówczas ci z Gorajca (katolicy) wszczęli fałszywy alarm, że tamtejsza cerkiew (od 1947 kościół rzymsko-katolicki) jest w tak złym stanie, że zsuwa się z „pecek". I roboty, i materiały przeniesiono tam właśnie. Efekt widać tu i tam.

Dwa małżeństwa $\mathrm{z}$ malutkimi dziećmi podjechały samochodami. Młode matki z łażącym już drobiazgiem poszły spacerowym krokiem „rzucić okiem”. Panowie mieli zaś role osobne. Jeden siedział obok samochodu, który stał z włączonym silnikiem. W klimatyzowanym wnętrzu spokojnie spała jego najmłodsza progenitura. Drugi gentleman wywlókł się z wnętrza samochodu, wystawiając nam wprost pod nos obie stopy. Widok był przykry. Poparzone, w krwistobladych

6 Folkowisko to Festiwal Kultury Pogranicza - impreza kulturalna odbywająca się we wsi Gorajec na Roztoczu. Jej celem jest kultywacja dziedzictwa kulturowego narodów zamieszkujących Galicję przed II wojną światową. W 2011 r. odbyło się pierwsze oficjalne Folkowisko. W wydarzeniu wzięło udział ok. 500 osób. Pod patronatem Andrzeja Stasiuka wystąpili ludowi opowiadacze, śpiewano dumki ukraińskie, zaprezentował się zespół folkowy z Ukrainy, zwiedzano okolicę oraz odnowioną gorajecką cerkiew. 
plamach i wilgotnych pęcherzach. Wyglądało, że nie wyszło coś przy skoku przez ognisko na wczorajszej nocnej imprezie [...].

Trochę czasu zeszło, gdy ponownie zostaliśmy sami, na dokładne zwiedzenie cmentarza. $Z$ jego perspektywy ruina cerkwi wyglądała ciekawie i malowniczo. Robiłem zdjęcia, ale nie wiem czy są w stanie oddać klimat; w tle monumentalne kilkumetrowe w obwodzie lipy, brąz ścian i rdzawość dachu cerkwi, rozpaczliwie zabite deskami okna. Drugi plan to pole zielonej kukurydzy podchodzące łanem pod samą świątynię i na planie pierwszym, ogromny w tym ujęciu, bruśnieński przydrożny krzyż. I jeszcze jedno zdjęcie - figura Matki Boskiej na jednym z nagrobków. Przygarbionej w cierpieniu, z oszpeconą twarzą. Wokół wysokie, brązowe harfy traw [...].

[...] Parokilometrowy dystans z Horyńca pokonaliśmy szosą o zdecydowanie gorszej nawierzchni. Rekompensowały to obłędnie piękne widoki rozległych panoram. A później Radruż, który nas zachwycił. Zjechaliśmy drogą w dół, by zatrzymać się u podnóża ogromnej drewnianej cerkwi. Otoczona murem z łupków krytych gontem, pyszniła się tak samo krytymi dachami. Obok stała drewniana i potężna dzwonnica. Wszystko zadbane, odnowione. Stary cmentarz za cerkwią, z wybielonymi krzyżami pochylonymi ze starości, nad mogiłami pozapadanymi $\mathrm{w}$ ziemię. Teren pomiędzy świątynią a cmentarzem wykoszono, oczyszczono z krzewów. Co to był za wspaniały widok. Tym bardziej że cerkiew i cmentarz posadowione były na dwóch krańcach wzgórza przeciętego wąwozem drogi. Miejscem i widokiem zostaliśmy oczarowani natychmiast. Ustawiliśmy rowery przed przymkniętą drewnianą bramą i ruszyliśmy na obchód, wzdłuż ogrodzenia. Świątynia z każdej strony prezentowała się okazale i potężnie. Na jej tyłach wiodła droga na następny cmentarz. Także oczyszczony z zarośli. Na nim więcej niż na pierwszym pomników, krzyży murowanych i kutych w kamieniu. Wszystko w bieli. Opisane po polsku i po ukraińsku. Malowniczo pochylone, stojące nieregularnie, aż gdzieś tam po drewniane ogrodzenie u góry. Przy wejściu dojrzeliśmy bryłę pomnika z „tryzubem” na froncie. Od razu było wiadome, że i w tym pełnym zadumy, malowniczym miejscu i to niekoniecznie po zmroku, wyłażą demony przeszłości. Wracaliśmy. Brama główna przed cerkwią pozostawała otwarta. Przed wejściem do świątyni, pod niskim daszkiem „,soboty” stało parę osób. Dołączyliśmy. Rej wodziła pani przewodniczka. Kobieta sympatyczna, dojrzała, o przemiłej twarzy i głosie. Zagajała dowcipnie i ze swadą. Zakupiliśmy bilety i zaczęła opowieść o obronnej cerkwi w Radrużu. Zainteresowanych odsyłam do specjalistycznych przewodników i opisów zabytku. Sam zaś, z głębi emocji jakie towarzyszyły naszemu pobytowi w tym niezwykłym miejscu, pragnę dodać, że jest wyjątkowe i dlatego, że przetrwało w niezmienionej postaci od późnego średniowiecza po chwilę obecną. Drewniana cerkiew przetrwała najazdy tatarskie. Przetrwała niespokojne XVI i XVII stulecie, pożogi wojen, szaleństwo krwawych politycznych bratobójczych podziałów, rozbiorów, anektowań, zmian systemów, obłęd niemieckiej furii, sowieckiego komunizmu, ukraińskiej zapalczywości, polskiej obojętności. Przetrwała podpalenia, kradzieże, dewastację i zniszczenia. Trwała piękna i potężna z bogactwem wyposażenia. Zniszczeń, których nie dokonały wszystkie wymienione plagi, zaczęła dokonywać ludzka 
głupota i obojętność. Najwięcej kradzieży i dewastacji poczyniono tam współcześnie, między końcem lat 40. a 80. XX wieku. Chwała więc tym, którzy przytomnie doprowadzili do gruntownego odremontowania świątyni. Tym, którzy zadecydowali o zabezpieczeniu bezcennego wyposażenia w muzeach w Łańcucie i Lubaczowie. Jego część znalazła się także we Lwowie. Budowla odnowiona, zabezpieczona i doceniona, czeka na powrót wyposażenia, dzieł sztuki. Podobno ma to się wydarzyć w 2012 roku. Oby.

[...] Po obejściu cerkwi, przez niskie wrota weszliśmy do jej mrocznego wnętrza. Odrestaurowane, stało puste w oczekiwaniu świątynnego wyposażenia. Dzięki temu, pomijając drewniane rusztowania, widać było dokładnie konstrukcję świątyni, kunsztowną robotę ciesielską, ogromne bale modrzewia, sosen i dębów, z których była zbudowana.

Tam zakończyła się część oficjalna zwiedzania. Grupa rozeszła się. Parę osób poszło obejrzeć dzwonnicę. Staliśmy, rozmawiając o tym, co dzieje się obecnie. Nie dawały mi spokoju pomniki z „tryzubem”. W odpowiedzi usłyszeliśmy o regularnych wycieczkach autokarowych z nieodległej Ukrainy. Dwa, trzy razy w roku. Słuchaliśmy o zachowaniach uczestników. O groźbach, przekleństwach pod adresem Polaków. Odmowie płacenia za bilet, zrywaniu krzyży katolickich. O starszych Ukrainkach, które wychodząc jako ostatnie z cerkwi, robiły pod adresem przewodniczki charakterystyczny pociągły gest ręką po szyi. O okrzykach: czyja to ziemia, jakich ojców. Wsio budu nasze! O tajemniczym wyrastaniu po takich wizytach całkiem sporych pomników z ,tryzubem”, z listą bohaterskich rezunów, którym chwała, bo polegli za wolną Ukrainę. Jechaliśmy przez ostatnie dwa dni szlakiem takich pamiątek [...]. Pomniki postawione stoją aż po tę chwilę. A jeśli ktoś w swojej zapalczywości i w poczuciu krzywdy, pod osłoną ciemności niszczył napis, ten sam napis, pod osłoną ciemności ktoś inny naprawiał. Demony czuwały. Ukazywały się w lokalnej prasie publikacje o władzach Horyńca-Zdroju. O niektórych przedstawicielach Rady Gminy sprzyjających szalenie takiej „turystyce” z Ukrainy. Pomniki trwają. Usłyszeliśmy o Pani, miejscowej emerytce, pamiętającej lata $40 . \mathrm{XX}$ w. Z uciułanych pieniędzy sfinansowała prosty krzyż i metalową tabliczkę z nazwiskami ofiar „bohaterów” spod znaku „tryzuba”. Byli na tej liście Polacy, Ukraińcy z mieszanych małżeństw, którzy nie chcieli walczyć ramię w ramię z faszystami z UPA. Skończyli strasznie. Dosłownie wythuczono wszystkich. Od dziadka począwszy, na wnuku niemowlęciu kończąc. Emerytka samotnie upomniała się też o pamięć o Żydzie Abramku, pachciarzu $\mathrm{z}$ przedwojennego majątku, ukrywającym się $\mathrm{w}$ wojnę $\mathrm{z}$ chorym dzieckiem. Jego kryjówkę odkrył i wydał ukraiński wójt. Żyda zatłukli sztachetami dawni ukraińscy sąsiedzi, w biały dzień, na środku wsi. Najpierw jednak ubili dziecko. Ciało kazali nieść ojcu przez wieś. Ci, którzy chowali się w domach słyszeli przez przymknięte okiennice niosący się z drugiego krańca wsi nieludzki skowyt Abramka. Tabliczkę zdjęto. Emerytowana nauczycielka ciągana była po najróżniejszych instytucjach. Oskarżana, a to o samowolę budowlaną, a to o inne tego typu bzdury. Tak tam jest. Jak zaczynasz dostawać skrzydeł na widok piękna okolicy, przyrody i cudów takich jak cerkiew w Radrużu, jak się trochę odrywasz od ziemi, zaraz to gaśnie. W mroku widać cienie. A przecież żyli tam obok siebie 
Polacy, Ukraińcy, Rusini, Żydzi, Litwini, Niemcy, Austriacy. Żyli katolicy, prawosławni, unici, judaiści, protestanci, kalwini, luteranie. Były mieszane związki, były wspólne dzieci, były wspólne interesy, były wspólne dla chrześcijan cmentarze. Modlili się po swojemu, w swoich kościołach. W tych kościołach później święcili noże, jedni na drugich. I mordowali. I nadal są ci, tak ślepo zapatrzeni, a niewidzący.

Był wczesny wieczór. Odjechały ostatnie samochody. Zostaliśmy sami. Przysiedliśmy przed cerkwią, by pobyć tam jeszcze trochę w ciszy [...]. Popatrzyliśmy na to miejsce, na słońce, zieleń, spokój, ciszę, na przyjazną sylwetkę świątyni za nami i jednogłośnie zapadła decyzja - zostajemy tam na noc. Było zbyt pięknie, by pobyć tak krótko, zbyt ciekawie, tajemniczo. [...] Na małym placu przed cerkwią postanowiliśmy rozłożyć się obozowiskiem. Dla pełnego spokoju poszedłem do odległego o kilkadziesiąt metrów domu, by dopytać o pozwolenie. Po obejściu chodził gospodarz, mężczyzna około czterdziestki, sympatyczny. Oświadczył, że to wiejski plac dla wszystkich. Mógł być dla nas polem namiotowym. Pokazał skąd mogę wziąć wodę i poszedł czyścić ryby. Rozłożyliśmy namiot na skraju pola, tyłem do wysokich traw i drogi, bokiem do gospodarstwa naszego sąsiada. Wejście skierowałem na radruską cerkiew, dokładnie tak, by leżąc na materacu, cały czas mieć ją przed oczami. Na placu obok umieszczono drewniane ławy i stoły. Przytachaliśmy we dwoje taką ławę pod nasz wakacyjny dom i na niej urządziliśmy kolację [...]. Przygotowywaliśmy sobie wieczorną strawę, popatrując co chwila na kompleks cerkiewny. A tam odgrywał się teatr światła, kolorów i cienia. Takiego piękna, które trudno wypatrzeć na co dzień. Zwłaszcza, kiedy jedzie się przez kraj nasz urodny, w którym w bród domów z pustaka. A gdy miało dojść do konsumpcji, doszedł do nas nowy sąsiad ze swoją malutką córeczką. Trochę boczyła się na nas, nic dziwnego. Przynieśli nam talerz okryty folią. Pod nią zaś świeżo usmażone, pachnące cudownie karasie. [...] Pan Andrzej, okazało się syn przewodniczki Janiny, odprowadził małą i powrócił. Mogliśmy swobodnie porozmawiać po kolacji. Wszystkie złota Persji za taki wieczór. Bardzo jesteśmy wdzięczni za uświadomienie, co to za miejsce wokół nas. Jak fantastycznie, że są tacy ludzie. Żyjący obok lasu, z drzewami na ty. Gdybyśmy zostali sami na przycerkiewnej łące, nigdy nie dowiedzielibyśmy się, że na północ od niej, na granicy z lasem od zawsze biegła droga. Wprost pod cerkiew. Pan Andrzej wskazywał. Widać było wyraźną linię drzew wzdłuż traktu. Powyżej stała karczma. Prowadził ją Żyd. Ruch miał zawsze spory. Miejsce przed nią, część polany, było ówczesnym parkingiem dla furmanek. Tu przepędzano konie, bydło $\mathrm{z}$ targu. W tej karczmie dobijano targu, załatwiano najróżniejsze interesy. $\mathrm{Tu}$, po jedynym niedzielnym nabożeństwie kończącym się około południa, skupiało się życie towarzyskie. Obok, po drugiej stronie drogi, gdzie w tej chwili rachityczny sad, stał dom owego właściciela austerii. Po domu nie został nawet ślad. Było pole, na którym pan Andrzej przeorał płytko zakopany gliniany garnek, a w nim stos ,boratynek”. Trzymałem w dłoni suwenir od pana Andrzeja. Malusieńką, ciemną monetkę, na której widać królewski profil w wieńcu laurowym, na rewersie orzeł polski z tarczą herbową Wazów [...]. Słuchaliśmy opowieści o tym, jak trzydzieści z okładem lat wstecz wyglądała okolica. Był tu PGR, chłopi 
indywidualnie trzymali bydło. Nie było jak teraz wysokich traw, krzewów i zarośli. Granica była widoczna tuż obok, jak na dłoni [...].

Noc była cicha i spokojna. Ocknąłem się świtem na parę chwil. Bez wychodzenia z namiotu w chłód poranka oglądałem w zachwycie jak między drzewami nad cerkwią świętej Paraskewy w Radrużu, bladozłotą kulą wstawało słońce.

\section{Budynin, 18.07.2011 r. (woj. lubelskie)}

[...] Ruszyliśmy w kierunku Tarmoszyna i Szczepiatyna. Cały czas otwartą przestrzenią, płasko i monotonnie. Poruszaliśmy się przygranicznym obszarem, doświadczanym walkami polsko-ukraińskimi, mordami i pogromami czynionymi przez Ukraińców z UPA, ,akcją Wisła” trwającą tu do końca 1947 roku, nowymi zasiedleniami ludnością z okolic Lublina. Akordem końcowym tej gehenny była kolejna ,akcja H-T”, czyli największa po wojnie „korekta” granicy z lutego 1951 r. Odkryto wtedy złoża węgla kamiennego na Sokalszczyźnie. Fakt ten oraz linia kolejowa Rawa Ruska-Sokal były głównymi powodami, dla których kolejny raz odebrano Polsce tę część ziem. Straciliśmy między innymi Uhnów, odebrano Bełz z jego zabytkami i kilkusetletnią historią związków z Rzeczpospolitą. Granica przecięła wsie, miasta, dzieląc jeden historyczny organizm. Jechaliśmy blisko. To, co przytaczał bedeker, dostrzegaliśmy na własne oczy. Oto wieś Korczmin. Dziwnie się przez nią przejeżdżało. $Z$ tego powodu, że na jakimś odcinku jej środkiem prowadziły dwie równolegle drogi. Środkiem płynęła struga zwana Rzeczycą. Korczmin słynął z cerkwi greckokatolickiej pod wezwaniem Objawienia Pańskiego. Cerkiew najstarsza w tym rejonie, z XVI wieku, odnowiona cudnie i tak też wyglądająca. Zaskakiwał jej kształt. Wąska i bardzo wysoka. Robiła wrażenie. Na wschód od niej, po drugiej stronie granicy biło źródło, tak ważne we wschodnim obrządku. Uroczystości religijne z procesją z cudownym obrazem, by przejść z cerkwi do tego źródła, wymagały zgody ministerstw w Warszawie i Kijowie, wojsk pogranicznych i kogo tam jeszcze. Kiedy uzyskano wszelkie zgody należało jeszcze przeciąć zasieki z drutu kolczastego, wysokie na ponad 2 metry. Słychać śmiech generalissimusa Stalina.

Śledząc ostatnie kilkadziesiąt lat dziejów świątyni, widać wyraźnie polski grzech zaniechania i obojętności. Jeśli zdarzają się cuda, to tak było w Korczminie. Budowla wyjątkowa jeśli chodzi o architekturę, miejsce posadowienia, już w czasach zaboru austriackiego była wpisana na listę zabytków. Wszystko właściwie było w niej wyjątkowe. Gdy podjechaliśmy, z bliska dzięki wysokiej i wąskiej bryle, wyglądała jak ogromny okręt. W tej monumentalnej postaci tak zwyczajnie posadowiona na polnych głazach i dębowych ,peckach”. Przez tę przestrzeń pod spodem nabierała specyficznej lekkości. Stąd wrażenie, że mogła odpłynąć. Przysiadłem na progu zakrystii. Pod nogami miałem stopień uczyniony z ogromnego, białego, jednorodnego bloku kamienia. Nie chciało nam się stamtąd ruszać. 
Historia okolicy i świątyni typowa dla tego rejonu kraju. Po wywiezieniu w ramach akcji „Wisła” ludności prawosławnej ze wsi, cerkiew została przekazana katolikom. Warto zauważyć, że przetrwała wojnę w dobrym stanie. Miała zostać kościołem filialnym parafii z pobliskiego Machniówka. Z powodu małej ilości wiernych porzucona, niszczała przez prawie pięćdziesiąt lat. Po kolei, w latach 1955, 1959, 1963 zagładzie ulegały kolejne jej części. Począwszy od zawalenia dachu i ścian zakrystii, poprzez zniszczenia kruchty i podłóg. Rozkradano także wnętrze. Byli jednak tacy, którym los świątyni leżał na sercu. Apelowali przez te wszystkie lata, gdzie było możliwe. Prośby o ratowanie cerkwi pisali mieszkańcy Korczmina. Także ci, których wysiedlono stamtąd. Polonia, diaspora ukraińska z Kanady, Francji. Na nic. Pojawiały się komisje muzealne, ministerialne. Stwierdzały, że stan techniczny zabytku jest zły. Nie ma nadziei na jego uratowanie. Ogromną pracę, by ocalić budowlę, wykonał dawny proboszcz Korczmina ksiądz Dymitr Bachiwski. Deportowany w 1946 roku do ZSRR, upominał się o ratowanie zabytku. Pisał do Kijowa do odpowiednich ministerstw. Publikował apele w prasie, co w tamtych latach i miejscu było wielką odwagą. W 1990 roku ruinę cerkwi przejęła Społeczna Komisja Towarzystwa Opieki nad Zabytkami. Wykonano prace inwentaryzacyjne. Rozpoczęto remont od rozbiórki tego co pozostało, do podstaw. $\mathrm{Z}$ braku pieniędzy prace ciesielskie postępowały bardzo wolno, były wstrzymywane na lata. To co zdołano z trudem zrekonstruować, niezabezpieczone dachem zaczynało od nowa niszczeć. Tak było jeszcze w 2003 roku. Niszczały polichromie, brak było podłóg, stropów, legarów, okien, drzwi. Przede wszystkim dachu nad prezbiterium i babińcem. Sytuacja była tak tragiczna, że cerkiew wystawiono na... licytację. Tu pojawił się prawosławny duchowny rodem z Białego Boru, a póki co proboszcz parafii greckokatolickiej w Lublinie, ksiądz doktor Stefan Batruch. Dzięki jego staraniom własność cerkwi została przeniesiona na rzecz tejże parafii. Proboszcz dokonał cudu. Uruchomił łańcuch ludzi dobrej woli, którzy w odnowienie zabytku włożyli własną pracę i pieniądze. Nie chciało nam się wierzyć, że w miejscu, w którym siedzieliśmy oparci o ścianę zakrystii, dziewięć lat wstecz nie było niczego prócz ruiny. No to jest chyba cud właśnie? Ksiądz Batruch musi jakiś z powołania. Rekonsekrował świątynię, a potem poprowadził procesję do źródła w ukraińskiej Stajiwce. Chciałby nad tą rzeką pełną polsko-ukraińskiej krwi przerzucić most, jednocząc swymi działaniami. Z tym mostem to nie jest aż taka przenośnia. Oto ksiądz doktor zgłosił pomysł połączenia wiernych po obu stronach granicy. W Kryłowie, do którego zmierzaliśmy w swej wyprawie, chciałby przerzucić przez graniczny Bug pontonowy most. No, no... Działania tego człowieka, jego przesłanie były widoczne i w takiej inicjatywie, jak ustawienie przed cerkwią kamiennego krzyża, takiego z Brusna. Czytaliśmy napis na jego powierzchni, kuty głęboko i w taki sposób, że tekst po ukraińsku i po polsku przeplatał się wzajemnie: Na spomin usopszczich wsich (waro?) wiznan ta nacjonalnostie wićna im pamiac. R.B. - pamięci zmartych wszystkich wyznań, i narodowości pokój ich duszy. A.D. 2006. Nie było „tryzuba” i listy tych, co za wolną Ukrainę. Zastanawiałem się, jak długo...

Trudno było stamtąd odjeżdżać. Nawet myśleliśmy o tym, by szukać noclegu w Korczminie. Ale poza pięknem miejsca tu przy cerkwi, sama wieś robiła 
wrażenie pustej i obcej. Po kilkudziesięciu minutach spędzonych tam, po sesji fotograficznej z cerkwią i bez niej, postanowiliśmy jechać dalej. Na odjezdnym przyszła mi do głowy myśl, by w jedynym gospodarstwie usytuowanym najbliżej świątyni spytać o klucze i możliwość zajrzenia do wnętrza. Wjechałem na podwórko. Gospodarz robił coś przy traktorze, ujadała kudłata psina, bawiło się małe dziecko. Wyszła do mnie kobieta w średnim wieku. Odpowiedź była przecząca. Mało tego, usłyszałem coś co kompletnie mnie zaskoczyło; kluczy nie mieli, a cerkwi w środku nigdy nie oglądali. Po prostu nigdy tam nie byli, choć mieszkali obok, jak powiedziała pani, od zawsze. Nam było bliżej.

Minęliśmy Machnówek z gęstą zabudową wzdłuż drogi. Rozglądałem się za noclegiem. Droga biegnąca nieomal przy samej granicy skręcała pod kątem prostym, wjeżdżaliśmy do Budynina. Po prawej stronie Ukraina. Po horyzont czarnoziem. Wokół jeździło sporo traktorów. Mimo nadchodzącego wieczoru był to czas wytężonych prac. Z łuku drogi spoglądaliśmy na ukraińską stronę. W niezbyt dużej odległości widoczne były domy i wieże kościołów w Bełzie. Zatrzymaliśmy się, by utrwalić ten widok. Budynin wydał nam się dobrym miejscem do poszukania noclegu. Tuż obok rozsiadło się gospodarstwo z małym drewnianym domem. Taką prawie łemkowską bieloną chyżą wśród owocowych drzew. Podjechaliśmy do bramy, by zasięgnąć języka. I tam zostaliśmy na noc.

W Budyninie na nocleg przyjęli nas do siebie cudowni chaziaje. Pan Marian sterany robotą żylasty „,szczuplak” o pobrużdżonej twarzy, z nieodłączną czapką na głowie i tlącym się papierosem, oraz jego małżonka Urszula, zażywna i niezwykle ruchliwa niewiasta. Na podwórku tuż przed bramą mieliśmy po pół godzinie rozbity namiot [...]. Umęczeni upałem i drogą cieszyliśmy się z tego miejsca. Gospodarze byli otwarci i serdeczni, jak tylko można sobie wymarzyć. Miejsce, choć przy drodze, ciche i spokojne. Zaprosili, byśmy siedli z nimi przy stole. Rozpościerał się nad nim eternitowy daszek. Chcieliśmy przygotować sobie wieczorny posiłek. Nie było mowy. Gospodyni zaserwowała gorące porcje ziemniaków wraz z osmażaną kiełbasą z cebulą i panierowane pieczarki, do tego mizeria... Faktycznie, od momentu naszego wejścia przez cały czas, pani domu obierała coś, przygotowywała, pichciła. Nie spodziewaliśmy się, że robiła to specjalnie dla nas. [...] W ten gorący wieczór, po trudach dnia siedzieliśmy długo w noc, rozmawiając. Szalenie serdeczni, otwarci ludzie. Budynin stał się ich domem w latach 50. XX w. Rodzina pana Mariana dotarła w ten rejon z okolic Lublina $\mathrm{z}$ terenu pomiędzy Chodlem a Bełżycami. Tu osiedli na gospodarce pozostawionej przez Ukraińców, remontując domek, ową chyżę. Po latach ich dzieci dorosły i rozjechały się po Polsce. Daleko. Za Piłę, do Lublina i gdzieś tam jeszcze. Siedzieli sami na małym kawałku pola. Gospodarzyli. Coś uchowali, coś zaoszczędzili i dla dzieci to, tylko dla dzieci. Nie było im łatwo wychować całą czwórkę. Dom niewielki. Gospodarka mała. Pan Marian wspominał, jak kiedyś tam się żyło. Jak handlowało z „Ruskimi”. Jak po 1951 roku, po owej „korekcie” granicznej, nocami trwały już po „tamtej” stronie próbne odwierty w poszukiwaniu złóż węgla. Całymi miesiącami i wyłącznie w nocy. Dudniło i warczało z odległości tego kilometra z okładem jaki dzielił ich dom od „nowej” granicy. Drżała 
ziemia, drżały naczynia w kuchennej szafce. Wielki Brat realizował misję dziejową. Gospodarz opowiadał, jak głęboko w kopalniach, które są tuż przy granicy, w okolicach Uhnowa, ale i przy najbliżej położonym Korcziwie, sięgają w głąb Polski korytarze. Że kilometr w pionie, a kilkanaście kilometrów pod nami. Któż to wie, ,Rusek” potrafił. Opowiadał, jak z dnia na dzień zniknęła woda w studni. Przyjechali hydrolodzy i szukali nowego ujęcia na podwórku. Nie kopali tradycyjnej studni. Zrobili odwiert i podłączyli się do niego z instalacją. Trafili za pierwszym razem. Wstaliśmy od stołu, pan Marian prowadził pod domek wskazując miejsce. Podobno z płytkiego odwiertu woda biła w górę wyżej domu.

- Tak wysoko! - pan Marian wskazywał ręką ponad dachem - waliła prawie przez tydzień. - Obudowali ją instalacją. Jak zapewniał gospodarz ujęcie czynne do chwili obecnej, choć woda już inna w kranach, bo z wiejskiego wodociągu. Wzięliśmy po zimnym piwku i poszliśmy na drogę, tuż przed dom. W wieczornej szarówce robiłem zdjęcia. Trochę chmurzyło się niebo, ale malowniczo. W tym mroku widać było dokładnie Bełz, wieże kościołów. Tak blisko. Nie było więcej niż dwa, trzy kilometry w linii prostej. A ponieważ płasko i bezdrzewnie - widok wspaniały.

Od jesieni 1951 roku stary, malowniczy, polski Bełz stał się radzieckim Bietzem. Teraz to miasteczko ukraińskie. Ciekawostką jest to, że w czasach sięgającego tu zaboru austriackiego do 1914 roku pozostawał przejściem granicznym między Monarchią Austro-Węgierską a Rosją. Mieszkali tam w większości Żydzi, których na początku XX wieku było bez mała 4000, na ogólną liczbę ponad 6000 mieszkańców. Ukraińców było 1600, a Polaków 900.

W swej długiej i barwnej historii miasto przechodziło $\mathrm{z}$ rąk do rąk. Było jednym z Grodów Czerwieńskich, należało do Rusi Kijowskiej, było samodzielnym Księstwem Bełskim, leżało na obszarze Rusi Halicko-Wołyńskiej, pozostawało pod jurysdykcją litewską, węgierską, austriacką, niemiecką. Znalazło się na obszarze Zachodnioukraińskiej Republiki Ludowej. Należało do Polski. Trwał tam prawdziwy kresowy konglomerat. Osobną grupę stanowili zawsze Żydzi. Bełz miał własną dynastię cadyków i w XIX wieku pozostawał silnym ośrodkiem chasydzkim. Owa dynastia Betzer Rebbe nosi nazwisko Rokeach. Oczywiście Żydzi bełscy w czasie hitlerowskiej nocy podzielili los swych pobratymców z całej Europy. Deportowani do obozu w Bełżcu, mordowani masowo w innych. Jednakże jednemu z Betzer Rebbe, Aharonowi Rokeach udało się w czasie wojny uciec i przedostać do Palestyny (!). Tam odbudował bełską dynastię chasydzką.

Spoglądaliśmy z drogi na zabudowania miasta. Kręciło się w głowie od tych wszystkich historii. Żałowaliśmy, że nie było możliwości, by podczas naszego objazdu przejechać rowerami tych parę kilometrów i zobaczyć Bełz z bliska. A może i dobrze? Mniej rozczarowań. W następnnym roku dotarłem do Bełza z wycieczką autokarową. Był to wstrząs!

Staraliśmy się przypomnieć sobie tekst piosenki o miasteczku Bełz. Śpiewała ją Magda Umer. Smutna, nostalgiczna muzyka. Tekst pełen tęsknoty za miejscem urodzenia. Nuciłem sobie pod nosem motyw melodii, do słów refrenu: Miasteczko Betz, kochany mój Betz..., ale niestety nie pamiętałem nic więcej. Jakież było nasze zaskoczenie, gdy po powrocie sięgnąłem po pełny tekst utworu 
i jego historię. Wyszło, że to nie ten Bełz. Żydowski autor tekstu Jacob Jacobs opiewał miejsce swego dzieciństwa, miasteczko Balti, na terenie dzisiejszej Mołdawii. Nazwa miasteczka Balti w jidisz brzmi „Bełts”. Fonetycznie brzmi podobnie jak nazwa Bełza znad Sołokiji. Ot, siurpriza!

Zmęczenie zaczynało dawać się we znaki. Tyle wrażeń. Niezmordowany pan Marian opowiadał jeszcze historię Budynina. Powracał motyw ukraińskich korzeni nielicznych obecnych mieszkańców. $Z$ opowieści przebijało mroczne tło. Ogarniał wtedy smutek. Nie wiadomo co trzeba czynić, by w tym rejonie Polski mieli rację tacy, jak proboszcz greckokatolicki z Lublina, ksiądz doktor Stefan Batruch [...]".

Na potrzeby niniejszej publikacji dane osobowe prezentowanych postaci zostały zmienione, bądź jak w przypadku nazwisk, ograniczone do inicjałów. Wynika to z obowiązujących przepisów prawnych, pomijając fakt, że od opisywanych tu osób, uzyskano akceptację na ukazanie historii ich życia. W paru przypadkach na porządku dziennym był jednakże opór, powodowany nie kwestiami prawnymi, lecz strachem przed opublikowaniem, „ujawnieniem”, jak określono, ich późniejszych losów. Strach bowiem i przymus leżące u podłoża przesiedleńczej gehenny, trauma będąca efektem tego, pozostają żywe po dziś dzień.

Propagandowe akcje mające na celu zachętę do dobrowolnych przenosin, publikacje ${ }^{7}$ na ten temat po stronie polskiej, szły w parze ze strachem i prześladowaniami wskutek działań władz radzieckich. Jednocześnie bowiem z promowaniem powrotu do ojczyzny, choć nie na ziemię ojców, odbywały się przymusowe akcje wywożenia w głąb Związku Radzieckiego, aresztowania, niszczenie poczucia więzi narodowych poprzez pozbawianie możliwości rozwoju intelektualnego, społecznego, zawodowego ${ }^{8}$. Czyniono to na tyle skutecznie, że do końca lat 40. XX w. mieszkańcy Kresów Wschodnich polskiego pochodzenia uznali za pewnik nieuchronność zmian. Ich „[...] Przesiedlenie [...] w 1944 roku, tj. gdy toczyła się wojna, oznaczało zgodę na nową linię graniczną, przesądzało o nieodwracalności granic. Natomiast pozostanie na miejscu, to była walka o polskość Kresów, gdyż wyjazd oznaczał zgodę na ich utratę. Konferencja jałtańska wyznaczała wybór"'.

Wyjątkową sytuacją dla piszącego te słowa była okazja osobistego poznania przesiedlanych. Ich relacje są bardzo prawdziwe i niezwykle emocjonalne, tym

7 Np: Kraj wzywa, [w:] „Tygodnik Informacyjny Repatriant”, Warszawa 1946, ss. 30; Na zachód, Wydawnictwo Państwowego Urzędu Repatriacyjnego, Rzeszów 1945, ss. 84.

8 „Polityka przemieszczeń od samego początku natrafiała na przeszkody władz radzieckich, które dążyły do zminimalizowania jej zasięgów i rozmiarów, zwłaszcza osób pracujących w przemyśle, górnictwie i rolnictwie. Dlatego też poza ignorancją wobec zgłaszających się na wyjazd, prowadzona była szeroka agitacja polityczna przeciwko wyjazdowi do Polski. Polegało to głównie na pokazywaniu jej napiętej sytuacji społecznej, politycznej, narodowościowej i gospodarczej. $Z$ różnych stron ZSRR napływały do Ambasady Polski skargi na stwarzane trudności ze strony władz radzieckich przy określaniu narodowości, likwidacji nieruchomości i inwentarza, przedłużanie terminów wydawania dokumentów [...]". J. Czerniakiewicz, Przemieszczenia ludności polskiej z ZSRR 1944-1959, Warszawa 2004, s. 65 .

9 Tamże, s. 29. 
samym cenne. Osobną kwestią pozostaje korelacja ich wspomnień z okresu przeniesień, młodości, z chwilą obecną. Nie we wszystkich przypadkach nowe miejsce stało się ową „małą ojczyzną”, nie wszyscy, mimo upływu lat czuli się jak u siebie. Jedna z napotkanych osób (w Zachodniopomorskiem) stwierdziła, że nigdy się tam nie odnajdzie, ponieważ na Kresach pozostały groby bliskich. Inna zaś, zamieszkująca pogranicze z obwodem kaliningradzkim, mimo naszych propozycji wspólnego odwiedzenia granicy w tym miejscu, towarzyszyła nam tylko do pewnego punktu, zawracając kilkaset metrów stamtąd, miałem wrażenie z głęboką obawą, jeśli nie strachem. Tu, tytułem dygresji, ale także w podsumowaniu powyższych spostrzeżeń dodam, że dotarłem wtedy do granicy państwa z obwodem kaliningradzkim i dostrzegłem, że linia graniczna w tym miejscu przecinała równo na dwie części poniemiecki cmentarz. Symbolika tej sytuacji i miejsca była porażająca.

W podsumowaniu należy wspomnieć, że w okresie 1955-1959 do Polski z byłych Kresów Wschodnich powróciło ponad 90\% pozostałych tam jeszcze osób narodowości polskiej ${ }^{10}$. Można to nazwać głównym nurtem przesiedleń, którego intensywności należałoby upatrywać w międzynarodowym odprężeniu polityczno-wojskowym w efekcie ocieplenia relacji pomiędzy Stanami Zjednoczonymi Ameryki Północnej a Związkiem Radzieckim. Nie bez znaczenia także pozostawał fakt przesileń politycznych 1956 roku w Polsce, przynoszących chwilową demokratyzację życia, ale i także system polityczny ZSRR dokonujący, „pełzającej" rusyfikacji i sowietyzacji terenów zaanektowanych po 17 września 1939 roku. System kwestionujący wobec zamieszkujących te tereny Polaków ich narodową odrębność i takież ambicje.

\section{Summary}

\section{Migrants from the Eastern Areas of the Second Polish Republic after the Second World War - Reported by a Cycling Traveler}

The author presents three excerpts from the reports of cycling travel in Poland in the years 2008-2011, contained in the "Bicycle Journals". They contain descriptions of meetings with Poles who, as a result of political change in the areas of eastern Poland after 1945, were forcibly resettled in central, or north-western and western parts of Poland within its current borders.

10 „[...] W spojrzeniu na liczbę ludności polskiej przesiedlonej z ZSRR 1944-1948, konieczne jest ustalenie, jaka liczba obywateli polskich, narodowości polskiej i żydowskiej, zamieszkiwała w czasie rozpoczęcia akcji przesiedleńczej na obszarze między wschodnią granicą Polski z 1939 a granicą z 1944 r. Sprawa ta napotyka na poważne trudności, które uwarunkowane są charakterem statystyk ludności sporządzonych w latach 1921 i 1931, z których historyk musi korzystać [...]”; tamże, s. 135; w 1955-1959 „,...] do Polski wróciło 259420 osób [...], w tym, 18743 (7,01\%) osób narodowości żydowskiej. Prawie wszyscy pochodzili z europejskiej części ZSRR - 89,62\% (232 507 osoby)”. J. Czerniakiewicz, M. Czerniakiewicz, Przesiedlenia ze Wschodu 1944-1959, Warszawa 2007, s. 67. 
The direct accounts of the participants of the events show the complicated political background of Poland, Europe and the world after the Second World War, as well as the dramatic fate of the individuals.

Keywords: migrants, biographies, relationship, bicycle trip

\section{Bibliografia}

Bojarski P., Bagaż doświadczeń i wspomnień: relacje osadników polskich na Warmii i Mazurach po 1945 roku, Olsztyn 2017, ss. 191.

Czerniakiewicz J., Przemieszczenia ludności polskiej z ZSRR 1944-1959, Warszawa 2004, ss. 80.

Czerniakiewicz J., Przemieszczenia Polaków i Żydów na Kresach Wschodnich II Rzeczypospolitej i w ZSRR: 1939-1959, „Studia i Materiały”, z. 21, Warszawa 1991, ss. 15.

Czerniakiewicz J., Czerniakiewicz M., Przesiedlenia ze Wschodu 1944-1959, Warszawa 2007, ss. 157.

Eberhardt P., Migracje polityczne na ziemiach polskich (1939-1950), Wrocław 2010, ss. 264.

Halicka B., Polski Dziki Zachód: przymusowe migracje i kulturowe oswajanie Nadodrza 1945-1948, Kraków 2015, ss. 434.

Kersten K., Repatriacja ludności polskiej po II wojnie światowej: studium historyczne, Wroclaw 1974, ss. 274.

Kochanowski J., Deportacja zwana repatriacja, „Polityka. Pomocnik Historyczny” Z Kresów na Kresy, z dn. 12.09.2016.

Kosiński A. G., Dzienniki rowerowe 2008-2011, cz. I-II, Łódź 2018, ss. 643.

Kraj wzywa, ,Tygodnik Informacyjny Repatriant”, Warszawa 1946, ss. 30.

Latuch M., Repatriacja ludności polskiej w latach 1955-1960 na tle zewnętrznych ruchów wędrówkowych, Warszawa 1994, ss. 260.

Na zachód, Wydawnictwo Państwowego Urzędu Repatriacyjnego, Rzeszów 1945, ss. 84.

Olejnik L., Polityka narodowościowa Polski w latach 1944-1960, Wydawnictwo Uniwersytetu Łódzkiego 2003, ss. 640.

Ruchniewicz M., Repatriacja ludności polskiej z ZSRR w latach 1955-59, Warszawa 2000, ss. 402.

Rymaszewski S., Wykarczowani zza Buga, Gdańsk 2001, ss. 592.

Siedlecki J., Losy Polaków w ZSRR w latach 1939-1986, Warszawa 1989, ss. 404. 